\title{
A meta-analysis method for identifying potential blood based protein markers associated with Alzheimer's disease
}

\author{
Nivithaa Subburaj ${ }^{1}$, Rani $\mathrm{P}^{1^{*}}$ \\ \{nivithaasubburaj@gmail.com ${ }^{1}$ rani.bio@psgtech.ac.in ${ }^{1}$ \} \\ Department of Biotechnology, PSG College of Technology, Coimbatore, Tamil Nadu, India $641004^{1}$
}

\begin{abstract}
The Alzheimer's disease (AD) is a persistent neurodegenerative disorder characterized by loss of memory and different cognitive capabilities which represents 60 to $80 \%$ of dementia. Present day Alzheimer's remedies just treat and postpone the deterioration of dementia manifestations. A biomarker could provide a detailed measurements of brain abnormality, which can aid in the early detection of disease in people who have very mild symptoms and also the treatments targets could be developed for the disease in its early stages, before irreversible brain damage or mental decline occurs. Individuals with Alzheimer's disease and different types of dementia progress at various rates, and biomarkers may aid in predicting and monitoring their progression. Thereby researchers are looking for precise preclinical biomarkers for prognosis of cognitive impairment. The current methods that are used in AD diagnosis are expensive, invasive or time consuming. Hence there is a potential requirement for less invasive and economically feasible blood-based biomarkers to assist in large-scale screening of the geriatric population. The objective of this analysis was to evaluate the reported bloodbased protein biomarkers of Alzheimer's disease (AD). A methodical PubMed survey was performed on 1195 articles distributed among 2007 and March 2018 using the key phrases "Alzheimer's infection" and "plasma biomarker" and 58 articles were chosen that met with the filtering criteria. The blood-based proteins of $\mathrm{AD}$ from the selected papers were scored using a meta-scoring system.In this study, 90 blood based proteins were identified, of which 15 were reported multiple times. The six highest meta scored proteins are APOE, BNP, CRP, CD40, TNF $\alpha$ and Clusterin. Further examinations and broad trial validations are important to affirm the clinical use of these potential biomarkers for $\mathrm{AD}$ diagnosis.
\end{abstract}

Keywords: APOE, BNP, CRP, CD40, TNF.

\section{Introduction}

Alzheimer's disease (AD) is a chronic brain disorder that gradually destroys thinking abilities and memory, as well as the ability to perform simple tasks.AD represents about $60 \%$ to $70 \%$ of dementia cases. Despite the fact that the rate of progression varies, the average life span is around three to nine years once after diagnosis. Dementia affects at least 44 million people worldwide, making it a global health crisis that must be addressed. Around 4 million people are affected from varies forms of dementia in India. Alzheimer's disease affects around 1.6 million people worldwide. In India, the incidence of AD shows elevation in southern part than northern part, whereas comparably lower than China and other parts of the world. 
(Mathuranath et al., 2012) Although Alzheimer's affects the population with the age of 65 and above, approximately 200,000 Americans, have earlier onset of Alzheimer's disease based on age.

The cause of Alzheimer's disease is poorly understood. The known risk factors are increasing age, genetics, history of head injuries, depression and hypertension. The amyloid plaques and neurofibrillary tangles in the brain are linked to disease progress in AD.There are no medications or supplements that decrease the risk of acquiring AD. Drugs currently used for $\mathrm{AD}$ treatments cannot cure the disease but they can delay the progression of dementia symptoms. Thereby researchers seek highly accurate preclinical biomarkers for early diagnosis in order to minimize cognitive impairment.

Traditional AD biomarker detection has several defects, including invasiveness, low accessibility, high cost, and a narrow scope of clinical applicability. To rule out other possible causes, a probable diagnosis based on the patient's medical records and cognitive assessment (MMSE test), as well as medical imaging and blood tests. Initial symptoms are frequently misinterpreted as signs of normal ageing. Thorough examination of brain tissue for plaques and tangles, is required for a definitive diagnosis. MRI, CT, and PET scans are among the brain imaging techniques used. Blood biomarkers (BBs) have several advantages over CSF and neuroimaging biomarkers, including ease of access and minimal invasiveness.

Despite several attempts to detect AD-related BBs, the selection of reliable BBs has been hampered by low reproducibility. In this study, we will be screening the available protein BBs for $\mathrm{AD}$ to identify the prominent biomarkers for clinical diagnosis.

\section{Methodology}

\section{A. Article Selection}

The 'Alzheimer's Disease', and 'Plasma Biomarker' keywords were used to search the public PubMed electronic database. Out of all the 1195 hits the articles were sorted by publication date from 2007 up till 2018.

\section{B. Exclusion Criteria}

Only research articles written in English were considered for the study. Studies were excluded if they looked at other diseases, such as depression and diabetes, or if they didn't provide any clinical data. Studies that dealt with other types of AD biomarkers, such as miRNA, lipids, or ions, or other fields of interest, such as drug efficiency, were also excluded. Only protein biomarkers for which a database exists were chosen for further investigation because the discovery of new biomarkers is dependent on network analysis of previously reported biomarkers. Articles that only report on $\mathrm{A} \beta$ and tau proteins were excluded from the meta scoring step because they have been extensively studied previously and found to be less significant for AD diagnosis, and thus their inclusion could introduce bias into the system. Drug trials were excluded because the study's main goal was to find diagnostic markers for Alzheimer's disease. Articles that did not show a consistent change in BB levels were also excluded.

C. Inclusion Criteria

All the studies that were considered had to have at least one differentiating feature that distinguished normal subjects from those with Alzheimer's disease. All of the studies used the Mini-Mental State Examination (MMSE) score, which is a widely used scoring system for assessing a patient's cognitive status. Only biomarkers with their own ID were chosen from the 
Human Protein Reference Database (HPRD), and biomarkers with the same HPRD ID were counted multiple times.

D. The Meta Scoring System

Each protein BB will be scored using the equation.

$$
S(m \mathrm{i})=\sum_{p \in(p: m \mathrm{i} \in p)}\left(\sum_{c \in C} S(p, \mathrm{c})+\mathbb{S}(p, m \mathrm{i})\right)
$$

$S(m i)$ : Meta score of a biomarker mi

$$
\text { C: Set of criterion }
$$

mi:Protein

blood

biomarker

$S(p, c)$ : Score of a paper with a criterion c

$p$ : Paper

$\mathbb{S}(p, m i)$ : Significance score of a biomarker

c: Criterion $m$ in a paper $p$

It gives each protein $\mathrm{BB}$ a score based on the sum of two multiplied representative values: one is the score of the report stating the protein BB's statistical significance (p-value) derived from that report. Additional scoring was provided if other diagnostic methods were used to identify the AD subjects also: example: MMSE sample + MRI Brain Imaging and if it is a follow up study.

TABLE I Criteria of the meta-scoring system of Blood biomarkers of Alzheimer's

$\begin{array}{lllr}\begin{array}{l}\text { Criteria 1: Number of subjects } \\ \text { Number of Subjects }\end{array} & \text { Meta Score Given } & \begin{array}{l}\text { Disease } \\ \text { Criteria 3: MMSE } \\ \text { Welch's t-value of } \\ \text { MMSE Range }\end{array} & \text { M } \\ 0 & 0 & \text { NA } & 0 \\ 0-50 & 1 & <24.15 & 1 \\ 50-100 & 2 & \geq 24.15 & 2 \\ 100-150 & 3 & & \\ >150 & 4 & & \end{array}$

Criteria 2: Age

Welch's t-value of Meta Score Given P-Value

age range

0

$\geq 2.77$

$<2.77$

1

2
Criteria 4: Statistical Significance

Meta Score Given

NA

0

$\begin{array}{ll}0.01-0.05 & 1\end{array}$

$\begin{array}{ll}0.001-0.01 & 2\end{array}$ 
Table I Indicates four criteria for each report, with a representation of each scoring scale based on its sub-category. Based on their distribution patterns of the number of control and AD subjects scoring scales were assigned

The age criterion is scored by comparing the age of control and AD subjects in each article. The meta-scoring system also used the variation in MMSE scores between control and $\mathrm{AD}$ subjects as a criterion. We used Welch's t-test to give the study more weight, despite the fact that studies with greater MMSE differences were believed to have more accurate protein BBs.

To perform Welch's t test, we use the formula

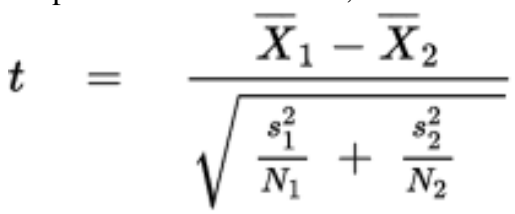

Where we compare the $\mathrm{AD}$ subjects statistics to the control's statistics (i.e., age and MMSE score) using the standard deviations observed in the study cohorts.

To determine the degree of reliability of each $\mathrm{BB}$, the statistical significance of the protein BBs shown in each article was examined.

\section{Results And Discussion}

In order to search in the Pubmed database, the keywords such as"alzheimer's disease" and "plasma biomarkers" were used in the study. Out of the 1195 hits in the Pubmed search engine,we had 955 articles upon applying the filtering criteria to exclude review articles, metaanalysis reports, and clinical trials. Reading through the abstracts we have excluded the non human studies, this step had to be done manually as many articles were not Medline indexed. Out of the 955, articles reporting only other types of markers like CSF, MRI, and other Brain imaging techniques to diagnose the AD subjects are excluded. Of the 642 remaining hits, articles reporting only amyloid-beta and tau markers, reports that show no characteristic change in the levels of $\mathrm{BB}$ and articles that do not use MMSE scores to measure the level of cognitive impairment (i.e. uses other imaging techniques to confirm $\mathrm{AD}$ ) were excluded leaving 58 articles which cumulatively report $90 \mathrm{BBs}$.

Table II summarize the information derived from the articles, while Fig. 1 depicts a schematic diagram of the review process adopted 


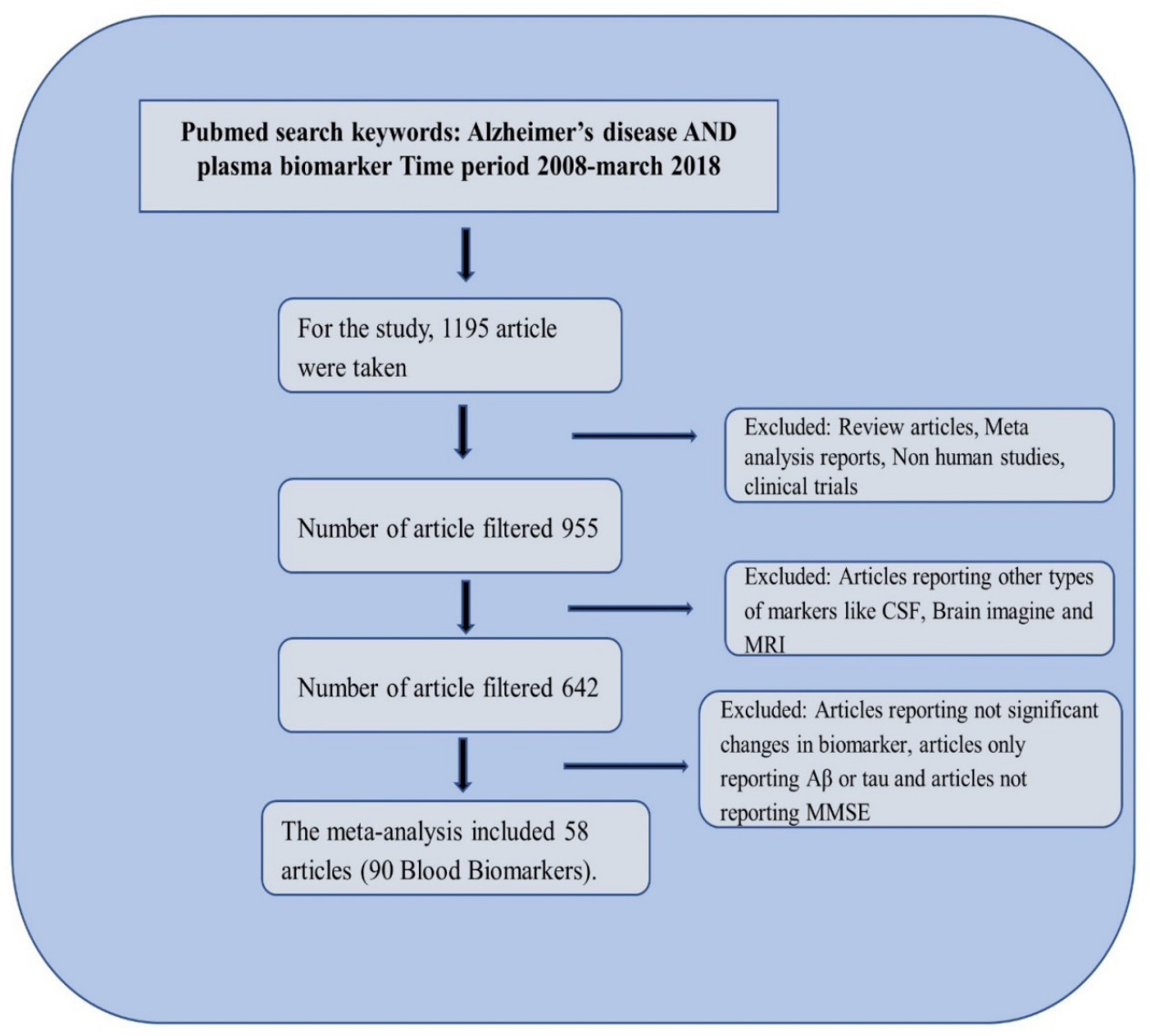

Fig. 1. Flow chart demonstrating the schematic of the systemic review and meta-analysis.

Each paper was reviewed and the proteins were listed and meta scored according to the four criterion, extra weightage was given to studies which were a follow up study or if they reported other diagnostic methods also to study the AD subjects. The meta score of all BBs listed were summed up have been reported in Table II

TABLE II The list of meta-scored protein biomarkers in blood for Alzheimer's disease diagnosis

\begin{tabular}{|l|l|l|l|l|l|}
\hline No & Biomarker & $\begin{array}{l}\text { Change in } \\
\text { biomarker in } \\
\text { AD compare } \\
\text { to control }\end{array}$ & $\begin{array}{l}\text { Meta } \\
\text { Score }\end{array}$ & Count & References \\
\hline 1 & APOE & $\begin{array}{l}\text { Increase or } \\
\text { decrease }\end{array}$ & 46 & 6 & $\begin{array}{l}\text { (Doecke et al., 2012; Guo, } \\
\text { Alexopoulos, Wagenpfeil, } \\
\text { Kurz, \& Perneczky, 2013; } \\
\text { Gupta, 2011; Hu et al., } \\
\text { 2012; Llano, Devanarayan, }\end{array}$ \\
\hline
\end{tabular}




\begin{tabular}{|c|c|c|c|c|c|}
\hline & & & & & $\begin{array}{l}\text { \& Simon, 2013; Soares et } \\
\text { al., 2012) }\end{array}$ \\
\hline 2 & $\mathrm{BNP}$ & Increase & 23 & 3 & $\begin{array}{l}\text { (Guo et al., 2013; Hu et al., } \\
\text { 2012; Llano et al., 2013) }\end{array}$ \\
\hline 3 & CRP & Decrease & 22 & 3 & $\begin{array}{l}\text { (Hall et al., 2013; Yarchoan } \\
\text { et al., 2013) }\end{array}$ \\
\hline 4 & CD40 & Increase & 20 & 3 & $\begin{array}{l}\text { (Ait-ghezala et al., 2008; } \\
\text { Buchhave et al., 2009; } \\
\text { Doecke et al., 2012) }\end{array}$ \\
\hline 5 & TNF $\alpha$ & Increase & 20 & 4 & $\begin{array}{l}\text { (Hall et al., 2013; Huang et } \\
\text { al., 2013; Kamer et al., } \\
\text { 2009; Kim et al., 2011) }\end{array}$ \\
\hline 6 & Clusterin & Increase & 18 & 3 & $\begin{array}{l}\text { (Deming et al., 2016; } \\
\text { Jongbloed et al., 2015; } \\
\text { Schrijvers, }\end{array}$ \\
\hline 7 & $\mathrm{PP}$ & Increase & 17 & 2 & $\begin{array}{l}\text { (Hu et al., 2012; Soares et } \\
\text { al., 2012) }\end{array}$ \\
\hline 8 & sTNFR1 & Increase & 17 & 2 & $\begin{array}{l}\text { (Faria et al., 2014; Zhang, } \\
\text { Jia, Qin, \& Wang, 2013) }\end{array}$ \\
\hline 9 & SGOT & Increase & 16 & 2 & $\begin{array}{l}\text { (Guo et al., 2013; Llano et } \\
\text { al., 2013) }\end{array}$ \\
\hline 10 & IL 8 & Decrease & 14 & 2 & 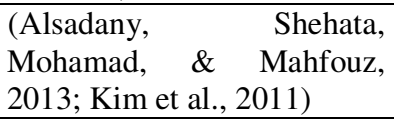 \\
\hline 11 & Homocysteine & Increase & 13 & 2 & $\begin{array}{l}\text { (Doecke et al., 2012; Hall et } \\
\text { al., 2013) }\end{array}$ \\
\hline 12 & BACE 1 & Increase & 12 & 2 & $\begin{array}{l}\text { (Goetzl et al., 2015; Wu et } \\
\text { al., 2012) }\end{array}$ \\
\hline 13 & BDNF & Decrease & 12 & 2 & $\begin{array}{l}\text { (Faria et al., 2014; Zheng et } \\
\text { al., 2016) }\end{array}$ \\
\hline 14 & MMP 2 & Increase & 11 & 2 & $\begin{array}{l}\text { (Doecke et al., 2012; Lim et } \\
\text { al., 2011) }\end{array}$ \\
\hline 15 & $\mathrm{~A} 1 \mathrm{M}$ & Increase & 10 & 1 & (Guo et al., 2013) \\
\hline 16 & BIN1 & Increase & 9 & 1 & $\begin{array}{l}\text { (Sun, Tan, Hu, Yu, \& Tan, } \\
\text { 2013) }\end{array}$ \\
\hline 17 & eotaxin 3 & Increase & 9 & 1 & (Soares et al., 2012) \\
\hline 18 & Gelsolin & Decrease & 9 & 1 & (Peng, Jia, \& Qin, 2015) \\
\hline 19 & IL 16 & Increase & 9 & 1 & (Guo et al., 2013) \\
\hline 19 & sLRP & Decrease & 9 & 1 & $\begin{array}{l}\text { (Liang, Jia, Wang, Qin, \& } \\
\text { Liu, 2013) }\end{array}$ \\
\hline 20 & sTNFR2 & Increase & 9 & 1 & (Zhang et al., 2013) \\
\hline 21 & TACE & Increase & 9 & 1 & (Zhang et al., 2013) \\
\hline 22 & AMP 1 & Increase & 8 & 1 & (Goetzl et al., 2015) \\
\hline 23 & Cathepsin & Increase & 8 & 1 & (Goetzl et al., 2015) \\
\hline
\end{tabular}




\begin{tabular}{|c|c|c|c|c|c|}
\hline 24 & CysC & Decrease & 8 & 1 & (Grewal et al., 2016) \\
\hline 25 & DHSM & Decrease & 8 & 1 & (Mielke et al., 2011) \\
\hline 26 & $\mathrm{HNE}$ & Increase & 8 & 1 & $\begin{array}{l}\text { (Rani, Krishnan, \& Rani } \\
\text { Cathrine, 2017) }\end{array}$ \\
\hline 27 & IGF II & Decrease & 8 & 1 & $\begin{array}{l}\text { (Hertze, Nagga, Minthon, \& } \\
\text { Hansson, 2014) }\end{array}$ \\
\hline 28 & IL 10 & Increase & 8 & 1 & (Doecke et al., 2012) \\
\hline 29 & IL 6 & Decrease & 8 & 2 & $\begin{array}{l}\text { (Huang et al., 2013; Kamer } \\
\text { et al., 2009) }\end{array}$ \\
\hline 30 & MAP K & Increase & 8 & 1 & (Kiddle et al., 2015) \\
\hline 31 & MAPKAPK 5 & Increase & 8 & 1 & (Kiddle et al., 2015) \\
\hline 32 & MMP 3 & Increase & 8 & 1 & (Peng et al., 2015) \\
\hline 33 & MMP 9 & Increase & 8 & 1 & (Doecke et al., 2012) \\
\hline 34 & PAI 1 & Increase & 8 & 1 & $\begin{array}{l}\text { (Oh, Lee, Song, Park, \& } \\
\text { Kim, 2014) }\end{array}$ \\
\hline 35 & PDS-TTR & Decrease & 8 & 1 & $\begin{array}{l}\text { (Bradley-Whitman, Abner, } \\
\text { Lynn, \& Lovell, 2015) }\end{array}$ \\
\hline 36 & sRAGE & Decrease & 8 & 1 & (Liang et al., 2013) \\
\hline 37 & Tenascin $\mathrm{C}$ & Increase & 8 & 1 & (Soares et al., 2012) \\
\hline 38 & TNF 2 & Increase & 8 & 1 & (Doecke et al., 2012) \\
\hline 39 & TTR & Decrease & 8 & 1 & (Velayudhan et al., 2012) \\
\hline 40 & Ubiquitin & Increase & 8 & 1 & (Goetzl et al., 2015) \\
\hline 41 & 24S-OH-Chol & Increase & 7 & 1 & (Zuliani et al., 2011) \\
\hline 42 & $\mathrm{ACE}$ & Increase & 7 & 1 & (Akatsu et al., 2011) \\
\hline 43 & Fibronectin & Increase & 7 & 1 & $\begin{array}{l}\text { (Lemańska-Perek, Leszek, } \\
\text { Krzyanowska-Goląb, } \\
\text { Radzik, \& Kạtnik- } \\
\text { Prastowska, 2009) }\end{array}$ \\
\hline 44 & GSH & Decrease & 7 & 1 & (Rani et al., 2017) \\
\hline 45 & GSSG & Decrease & 7 & 1 & (Rani et al., 2017) \\
\hline 46 & ICAM 1 & Increase & 7 & 1 & (Hall et al., 2013) \\
\hline 47 & IGBP 3 & Decrease & 7 & 1 & (Hertze et al., 2014) \\
\hline 48 & MDA & Increase & 7 & 1 & (Rani et al., 2017) \\
\hline 49 & PC Acrolein & Increase & 7 & 1 & (Waragai et al., 2012) \\
\hline 50 & SM & Decrease & 7 & 1 & (Mielke et al., 2011) \\
\hline 51 & sNRG -1 & Increase & 7 & 1 & (Chang et al., 2016) \\
\hline 52 & Adiponectin & Increase & 6 & 1 & (Une et al., 2011) \\
\hline 53 & APO CIII & Decrease & 6 & 1 & (Shih et al., 2014) \\
\hline 54 & APOA & Decrease & 6 & 1 & (Llano et al., 2013) \\
\hline 55 & APOE4 & Decrease & 6 & 1 & (Gupta, 2011) \\
\hline
\end{tabular}




\begin{tabular}{|c|c|c|c|c|c|}
\hline 56 & CHI3L1 & Increase & 6 & 1 & (Choi, Lee, \& Suk, 2011) \\
\hline 57 & CysC t1 & Increase & 6 & 1 & (Ghidoni et al., 2010) \\
\hline 58 & $\mathrm{HCY}$ & Increase & 6 & 1 & (Zheng et al., 2016) \\
\hline 59 & HDAC & Increase & 6 & 1 & (Alsadany et al., 2013) \\
\hline 60 & HSP70 & Decrease & 6 & 1 & (Goetzl et al., 2015) \\
\hline 61 & IL 15 & Increase & 6 & 1 & (Hall et al., 2013) \\
\hline 62 & LFP & Increase & 6 & 1 & $\begin{array}{l}\text { (Chmátalová, Vyhnálek, } \\
\text { Laczó, Hort, \& Skoumalová, } \\
\text { 2016) }\end{array}$ \\
\hline 63 & Neopterin & Increase & 6 & 1 & (Parker et al., 2013) \\
\hline 64 & NT-Pro BNP & Decrease & 6 & 1 & (Marksteiner et al., 2013) \\
\hline 65 & PGRN & Increase & 6 & 1 & (Piscopo et al., 2013) \\
\hline 66 & PON1 & Decrease & 6 & 1 & (Zengi et al., 2012) \\
\hline 67 & VCAM 1 & Increase & 6 & 1 & (Hall et al., 2013) \\
\hline 68 & YKL-40 & Increase & 6 & 1 & (Craig-Schapiro et al., 2010) \\
\hline 69 & YKL-40G & Increase & 6 & 1 & (Grewal et al., 2016) \\
\hline 70 & APO A1 & Decrease & 5 & 1 & (Kitamura et al., 2017) \\
\hline 71 & $\mathrm{C} 4 \mathrm{a}$ & Increase & 5 & 1 & (Bennett et al., 2012) \\
\hline 72 & CD40L & Increase & 5 & 1 & (Ait-ghezala et al., 2008) \\
\hline 73 & Fibrinogen & Increase & 5 & 1 & (Kitamura et al., 2017) \\
\hline 74 & Haptoglobin & Decrease & 5 & 1 & (Cocciolo et al., 2012) \\
\hline 75 & $\mathrm{HO}-1$ & Increase & 5 & 1 & (Di Domenico et al., 2012) \\
\hline 76 & N-truncated pGlu & Decrease & 5 & 1 & (Marcello et al., 2011) \\
\hline 77 & SUMO1 & Increase & 5 & 1 & (Cho et al., 2015) \\
\hline 78 & t HODE & Increase & 5 & 1 & (Yoshida et al., 2009) \\
\hline 79 & t8 iso PGF & Increase & 5 & 1 & (Yoshida et al., 2009) \\
\hline 80 & $\alpha-2$ Macroglobulin & Decrease & 5 & 1 & (Cocciolo et al., 2012) \\
\hline 81 & afamin & Decrease & 4 & 1 & (Kitamura et al., 2017) \\
\hline 82 & APO A4 & Increase & 4 & 1 & (Kitamura et al., 2017) \\
\hline 83 & BVR-A & Increase & 4 & 1 & (Di Domenico et al., 2012) \\
\hline 84 & GDNF & Increase & 4 & 1 & (Goetzl et al., 2016) \\
\hline 85 & IL I $\beta$ & Decrease & 4 & 1 & (Kamer et al., 2009) \\
\hline 86 & keratin 9 & Increase & 4 & 1 & (Richens et al., 2016) \\
\hline 87 & sAPP $\alpha$ & Increase & 4 & 1 & (Goetzl et al., 2016) \\
\hline 88 & sAPP $\beta$ & Increase & 4 & 1 & (Goetzl et al., 2016) \\
\hline 89 & $\begin{array}{l}\alpha-2-H S- \\
\text { Glycoprotein }\end{array}$ & Decrease & 4 & 1 & (Kitamura et al., 2017) \\
\hline
\end{tabular}




\begin{tabular}{|l|l|l|l|l|l|}
\hline 90 & $\gamma$ secretase & Increase & 4 & 1 & (Goetzl et al., 2016) \\
\hline
\end{tabular}

The Protein BB which was reported in most number of articles is APOE with a meta score of 46. Other significant BBs identified in the study are BNP, CRP, CD40, TNF $\alpha$, Clusterin, PP, sTNFR1 and SGOT.

The Protein $\mathrm{BBs}$ with the highest score are:

A. $A P O E$ (meta score $=46$ )

Alzheimer's studies show special curiosity towards ApoE 4 allele, which is capable of enhancing the possibility of late-onset Alzheimer's disease (LOAD) by two- to four-foldwhich is characterized by higher levels of amyloid plaques in the brain. While APOE proteins are higher in the blood plasma and CNS which helps in maintaining the neuronal membrane integrity, the genotype APOE4 is strongly responsible for the lower levels of ApoE protein, marking the onset and progression of AD. The presence of an ApoE 4 allele raised the risk of MCI-related AD progression. However,it'spositive and negative predictive valuesdid not support its use as a diagnostic marker forpredicting MCI to AD progression. In the context of research studies, however, it may be useful to enrich or stratify study samples of MCI subjects with faster progression of $\mathrm{AD}$. The number of $\mathrm{ApoE} 4$ alleles has been shown to influence CSF levels of the core AD biomarker candidates $\mathrm{A} \beta$, tau, p-tau, and beta-site amyloid precursor protein-cleaving enzyme-1(BACE1), therefore ApoE genotyping is commonly used in investigatory biomarker studies. The concentrations of serum or plasma ApoE protein levels in Alzheimer's disease have been reported to be inconsistent concluding that the ApoE protein levels cannot currently be recommended as a diagnostic biomarker for AD.(Schneider et al., 2009).

B. BNP (meta score $=23$ )

Gunstad J et al., in 2006 reported a link betweenBNP and cognitive function which was then correlated to the occurrence of new onset dementia in an elderly general population. In accordance with this above association, Hu et al., 2012 and Llano et al., 2013 also reported the elevated levels of BNP in AD.

Also, in the cardiac ventricles, the neurohormone B-type natriuretic peptide is produced. When ventricular myocytes are stretched, preproBNP is released, which is then cleaved into NT-proBNP and BNP by enzymes.Both BNP and NT-proBNP were concluded for their role in diagnosis of heart failure and adding to this, levels of NT-proBNP in plasma is 2-10 times higher than BNP in heart failure patients, with a half-life 3-6 times greater than BNP, suggesting it to be a more appealing biomarker.

C. $C R P$ (meta score $=22$ )

$\mathrm{C}$-reactive protein is produced in the liver in response to inflammation and injury; recent studies correlate the association of CRP levels to AD. According to neuropathology studies, neurofibrillary tangles and senile plaques are linked to CRP in AD brain. A 25-year follow-up study reported that midlife CRP elevations promoted the risk of vascular dementia (VaD) and late-life AD (Schmidt et al., 2002). Once the disease manifests, CRP levels appear to be lower in AD patients in a case-control study.Despite the fact that the significant lower levels of CRP in $\mathrm{AD}$ cases has been cross-validated across multiple cohorts, the link has not been validated in different ethnic groups. (O'Bryant et al., 2013)

D. $C D 40$ (meta score $=20)$

Chronic increased levels of membrane bound CD40 and its ligands CD40L and sCD40L result in the chronic inflammatory response resulting as the continuous activation of microglia in the brain which is strongly associated with AD disease pathology. 
In a follow-up study,compared to controls, no significant variation was observed in expression of sCD40 or sCD40L in MCI patients with stable cognition or who hadvascular dementia.But a correlation was seen between sCD40 levels and decreased baseline performance on MMSE. Also a correction was seen between the plasma levels of sCD40 and soluble forms of amyloid precursor proteins (sAPP- $\alpha$ and SAPP- $\beta$ ) in CSF.

sCD40 and sCD40L levels were higher in Alzheimer's disease and they were positively correlated with $A \beta 1-40$ and $A \beta 1-42$, respectively. They discovered that, combining sCD40, SCD40L, A $\beta$, and apolipoprotein $\mathrm{E}$ has contributed to high specificity and sensitivity inthe diagnosis of AD.

The above studies support the use of sCD40 and sCD40L as AD biomarkers; however, these measurements would be complemented with other biomarkers as a potential candidates with improved specificity and sensitivity. (Giunta, Rezai-Zadeh, \& Tan, 2010).

E. $T N F \alpha($ meta score $=20)$

Chronic inflammation, deposition of amyloid plaques, and intraneuronal accumulation of heavily phosphorylated tau protein forming tangles are the major AD pathological hallmarks. TNF- $\alpha$, a pro-inflammatory cytokine, is an important molecule in inflammation. Based on genetic and pharmacological manipulations, several in vivo studies have shown that TNFsignaling aggravates both $\mathrm{A} \beta$ and taurelated pathologies. Both preventive and interventional anti-inflammatory strategies were found to reduce brain pathology and improve cognitive function in AD rodent models (Decourt, Lahiri, \&Sabbagh, 2016).

F. Clusterin (meta score $=18$ )

Clusterin is a glycoprotein that primarily serves as an extracellular chaperone. Clusterin variants are strongly associated with the late-onset Alzheimer'sdisease as shown in large GWAS (Genome-Wide Association Studies), earning clusterin a spot on AlzGene's top 10 risk genes.

Clusterin levels are higher in $\mathrm{AD}$ brain, but it's unclear how the protein affects $\mathrm{AD}$ pathogenesis. This could be due to the fact the brain's ability to respond to stressors are impaired by pathogenic clusterin variants. The ability of clusterin to bind to A $\beta$ peptides and thus influence their aggregation, deposition, and/or clearance is a popular hypothesis, but the underlying mechanism(s) is still unknown. Clusterin variants are being linked to neurological phenotypes in functional studies. Clusterin can be found in blood and cerebrospinal fluid, but it has not yet proven to be a useful biomarker. (Clusterin I ALZFORUM., 2018)

According to Park et al. (2014), while the number of studies reporting certain high scoring BBs such as APOE, clusterin, and CRP has increased, the number of studies reporting new biomarkers is still limited. Additional research is required even in the case of high meta-scored protein Blood Biomarkers in order to confirm its clinical use as potential biomarkers and toimprove the mode of diagnosis.

\section{Conclusion}

Alzheimer's disease is a chronic brain disorder which ischaracterized by three major groups of symptoms: psychiatric symptoms, behavioral disturbances and cognitive impairment. Alzheimer's disease appears in a variety of forms; vary from mild memory loss to severe dementia. AD patients are frequently identified and treated in primary-care settings, can impose diagnostic and management challenges. Currently, stringent episodic memory tests (MMSE tests) are the only available best predictors of transition from mild cognitive 
impairment to AD.Cognitive impairments in multiple cognitive arenas are observed several years before the clinical onset of Alzheimer's disease that are stable for several years. (Burns \& Iliffe, 2009)

Early detection of cognitive impairment, as well as clinical assessment and management, postpones the need for nursing home care and lowers the risk of false diagnosis and irrelevant treatment strategies. The advantages of early Alzheimer's disease diagnosis include the initiation of symptomatic treatments for minimal cognitive impairment.

Even though imaging techniques can detect early changes in the brain, there is no single technique that could specifically identify people with MCI who can develop AD or other dementias if used as a screening test.

Traditional AD biomarker detection has a number of flaws, including invasiveness, high cost, limited accessibility and a narrow focus on clinical applicability. Blood biomarkers (BBs) have several advantages over CSF and neuroimaging biomarkers, including ease of access and minimal invasiveness.

There is an existing systemic review for identification of protein based blood biomarkers reporting the BBs that were identified from 1989 till march 2013 (Park et al., 2014). The objective of the present study is to review and score the BBs reported currentlythat could potentially be identified as useful in a clinical setting for diagnosis.

The Protein BB which was reported in most number of articles was APOE with a meta score of 46. Other significant BBs identified in the study are BNP, CRP, CD40, TNF $\alpha$, Clusterin, PP, sTNFR1 and SGOT. Further studies are necessary even for high meta-scored protein $\mathrm{BBs}$, to validate the potential biomarkers.

It appears unlikely that a peripheral biomarker would replace specific and consistent markers that are closer to the disease state such as PET imaging markers and CSF molecular markers. Peripheral biomarker will be less specific, but potentially more sensitive. They are undoubtedly easier to replicate in a broader population that necessarily involve repeated measurements to monitor disease progression. As an early step toward diagnosis in life, a funnel-based approach of blood-based biomarkers could be used. This would be a significant step toward making clinical trials effective and feasible.

\section{References}

[1] Ait-ghezala, G., Abdullah, L., Volmar, C. H., Paris, D., Luis, C. A., Quadros, A., ... Mullan, M. J. (2008). Diagnostic utility of APOE, soluble CD40, CD40L, and A $\beta 1-40$ levels in plasma in Alzheimer's disease. Cytokine, 44(2), 283-287. https://doi.org/10.1016/j.cyto.2008.08.013

[2] Akatsu, H., Ogawa, N., Kanesaka, T., Hori, A., Yamamoto, T., Matsukawa, N., \& Michikawa, M. (2011). Higher activity of peripheral blood angiotensin-converting enzyme is associated with lateronset of Alzheimer's disease. Journal of the Neurological Sciences, 300(1-2), 67-73. https://doi.org/10.1016/j.jns.2010.09.030

[3] Alsadany, M. A., Shehata, H. H., Mohamad, M. I., \& Mahfouz, R. G. (2013). Histone deacetylases enzyme, copper, and IL-8 levels in patients with Alzheimer's disease. American Journal of Alzheimer's Disease and Other Dementias, 28(1), 54-61. https://doi.org/10.1177/1533317512467680

[4] Alzheimer's Disease: Diagnosis I New York City. Retrieved April 22, 2018, from https://www.caringkindnyc.org/alzheimers-diagnosis/

[5] Alzheimer's Disease Fact Sheet. Retrieved April 19,2018, from https://www.nia.nih.gov/health/alzheimers-disease-fact-sheet

[6] Bennett, S., Grant, M., Creese, A. J., Mangialasche, F., Cecchetti, R., Cooper, H. J., ... Aldred, S. (2012). Plasma levels of complement 4a protein are increased in Alzheimer's disease. Alzheimer 
Disease and Associated $\quad$ Disorders, 26(4), 329-334. https://doi.org/10.1097/WAD.0b013e318239dcbd

[7] Bloom, G. S. (2014). Amyloid- $\beta$ and Tau. JAMA Neurology, 71(4), 505. https://doi.org/10.1001/jamaneurol.2013.5847

[8] Bradley-Whitman, M. A., Abner, E., Lynn, B. C., \& Lovell, M. A. (2015). A NOVEL PLASMA BASED BIOMARKER of Alzheimer'S DISEASE. Journal of Alzheimer's Disease, 47(3), 761771. https://doi.org/10.3233/JAD-150183

[9] Buchhave, P., Janciauskiene, S., Zetterberg, H., Blennow, K., Minthon, L., \& Hansson, O. (2009). Elevated plasma levels of soluble CD40 in incipient Alzheimer's disease. Neuroscience Letters, 450(1), 56-59. https://doi.org/10.1016/j.neulet.2008.10.091

[10] Burns, A., \& Iliffe, S. (2009). Alzheimer's disease. BMJ (Clinical Research Ed.), 338, b158. Retrieved from http://www.ncbi.nlm.nih.gov/pubmed/19196745

[11] Chang, K. A., Shin, K. Y., Nam, E., Lee, Y. B., Moon, C., Suh, Y. H., \& Lee, S. H. (2016). Plasma soluble neuregulin-1 as a diagnostic biomarker for Alzheimer's disease. Neurochemistry International, 97, 1-7. https://doi.org/10.1016/j.neuint.2016.04.012

[12] Chmátalová, Z., Vyhnálek, M., Laczó, J., Hort, J., \& Skoumalová, A. (2016). Analysis of lipophilic fluorescent products in blood of Alzheimer's disease patients. Journal of Cellular and Molecular Medicine, 20(7), 1367-1372. https://doi.org/10.1111/jcmm.12824

[13] Cho, S. J., Yun, S. M., Lee, D. H., Jo, C., Park, M. H., Han, C., \& Koh, Y. H. (2015). Plasma SUMO1 Protein is Elevated in Alzheimer's Disease. Journal of Alzheimer's Disease, 47(3), 639643. https://doi.org/10.3233/JAD-150103

[14] Choi, J., Lee, H.-W., \& Suk, K. (2011). Plasma level of chitinase 3-like 1 protein increases in patients with early Alzheimer's disease. Journal of Neurology, 258(12), 2181-2185. https://doi.org/10.1007/s00415-011-6087-9

[15] Clusterin I ALZFORUM. Retrieved April 19, 2018,from https://www.alzforum.org/alzpedia/clusterin

[16] Cocciolo, A., Di Domenico, F., Coccia, R., Fiorini, A., Cai, J., Pierce, W. M., ... Perluigi, M. (2012). Decreased expression and increased oxidation of plasma haptoglobin in Alzheimer disease: Insights from redox proteomics. Free Radical Biology and Medicine, 53(10), 18681876.https://doi.org/10.1016/j.freeradbiomed.2012.08.596

[17] Craig-Schapiro, R., Perrin, R. J., Roe, C. M., Xiong, C., Carter, D., Cairns, N. J., ... Holtzman, D. M. (2010). YKL-40: A novel prognostic fluid biomarker for preclinical Alzheimer's disease. Biological Psychiatry, 68(10),903-912. https://doi.org/10.1016/j.biopsych.2010.08.025

[18] Decourt, B., Lahiri, D., \& Sabbagh, M. (2016). Targeting Tumor Necrosis Factor Alpha for Alzheimer's Disease. Current Alzheimer Research, 13(999), 1-1. https://doi.org/10.2174/1567205013666160930110551

[19] Deming, Y., Xia, J., Cai, Y., Lord, J., Holmans, P., Bertelsen, S., ... Cruchaga, C. (2016). A potential endophenotype for Alzheimer's disease: cerebrospinal fluid clusterin. Neurobiology of Aging, 37, 208.e1-208.e9. https://doi.org/10.1016/j.neurobiolaging.2015.09.009

[20] Di Domenico, F., Baroneb, E., Mancuso, C., Perluigi, M., Cocciolo, A., Mecocci, P., ... Coccia, R. (2012). HO-1/BVR-A system analysis in plasma from probable Alzheimer's disease and mild cognitive impairment subjects: A potential biochemical marker for the prediction of the disease. Journal of Alzheimer's Disease, 32(2), 277-289. https://doi.org/10.3233/JAD-2012-121045

[21] Doecke, J. D., Laws, S. M., Faux, N. G., Wilson, W., Burnham, S. C., Lam, C. P., ... Martins, R. N. (2012). Blood-based protein biomarkers for diagnosis of Alzheimer disease. Archives of Neurology, 69(10), 1318-1325. https://doi.org/10.1001/archneurol.2012.1282

[22] Dubois, B., Padovani, A., Scheltens, P., Rossi, A., \& Dell'Agnello, G. (2016). Timely Diagnosis for Alzheimer's Disease: A Literature Review on Benefits and Challenges. Journal of Alzheimer's Disease : JAD, 49(3), 617-631. https://doi.org/10.3233/JAD-150692

[23] Faria, M. C., Gonçalves, G. S., Rocha, N. P., Moraes, E. N., Bicalho, M. A., Gualberto Cintra, M. T., ... Sousa, L. P. (2014). Increased plasma levels of BDNF and inflammatory markers in Alzheimer's disease. Journal of Psychiatric Research, 53(1), 166-172. https://doi.org/10.1016/j.jpsychires.2014.01.019 
[24] Ghidoni, R., Benussi, L., Glionna, M., Desenzani, S., Albertini, V., Levy, E., ... Binetti, G. (2010). Plasma cystatin $\mathrm{C}$ and risk of developing Alzheimer's disease in subjects with mild cognitive impairment. Journal Of Alzheimer's Disease: JAD, 22(3), 985-991. https://doi.org/10.3233/JAD2010-101095

[25] Giunta, B., Rezai-Zadeh, K., \& Tan, J. (2010). Impact of the CD40-CD40L dyad in Alzheimer's disease. CNS \& Neurological Disorders Drug Targets, 9(2), 149-155. Retrievedfrom http://www.ncbi.nlm.nih.gov/pubmed/20205645

[26] Goetzl, E. J., Boxer, A., Schwartz, J. B., Abner, E. L., Petersen, R. C., Miller, B. L., \& Kapogiannis, D. (2015). Altered lysosomal proteins in neural-derived plasma exosomes in $\begin{array}{lllll}\text { preclinical Alzheimer } & \text { disease. }\end{array}$ https://doi.org/10.1212/WNL.0000000000001702

[27] Goetzl, E. J., Mustapic, M., Kapogiannis, D., Eitan, E., Lobach, I. V., Goetzl, L., ... Miller, B. L. (2016). Cargo proteins of plasma astrocyte-derived exosomes in Alzheimer's disease. FASEB Journal, 30(11), 3853-3859. https://doi.org/10.1096/fj.201600756R

[28] Grewal, R., Haghighi, M., Huang, S., Smith, A. G., Cao, C., Lin, X., ... Selenica, M. L. B. (2016). Identifying biomarkers of dementia prevalent among amnestic mild cognitively impaired ethnic female patients. Alzheimer's Research and Therapy, 8(1), 1-11. https://doi.org/10.1186/s13195016-0211-0

[29] Gunstad, J., Poppas, A., Smeal, S., Paul, R.H., Tate, D.F., Jefferson, A.L., Forman, D.E. \& Cohen, et al. (2006). Relation of brain natriuretic peptide levels to cognitive dysfunction in adults $>55$ years of age with cardiovascular disease. American journal of cardiology, 98(4), 538-540. https://doi.org/10.1016/j.amjcard.2006.02.062

[30] Guo, L. H., Alexopoulos, P., Wagenpfeil, S., Kurz, A., \& Perneczky, R. (2013). Plasma proteomics for the identification of alzheimer disease. Alzheimer Disease and Associated Disorders, 27(4), 337-342. https://doi.org/10.1097/WAD.0b013e31827b60d2

[31] Gupta, V. B. (2011). Plasma apolipoprotein E and Alzheimer disease risk. Neurology, 76, 10911098. Retrieved from http://dx.doi.org/10.1212/WNL.0b013e318211c352

[32] Hall, J. R., Wiechmann, A. R., Johnson, L. A., Edwards, M., Barber, R. C., Winter, A. S., ... O'Bryant, S. E. (2013). Biomarkers of vascular risk, systemic inflammation, and microvascular pathology and neuropsychiatric symptoms in Alzheimer's disease. Journal of Alzheimer's Disease,35(2),363-371. https://doi.org/10.3233/JAD-122359

[33] Hertze, J., Nagga, K., Minthon, L., \& Hansson, O. (2014). Changes in cerebrospinal fluid and blood plasma levels of IGF-II and its binding proteins in Alzheimer's disease: an observational study. BMC Neurology, 14, 64. https://doi.org/10.1186/1471-2377-14-64; 10.1186/1471-2377-1464

[34] Hu, W. T., Holtzman, D. M., Fagan, A. M., Shaw, L. M., Perrin, R., Arnold, S. E., ... Soares, H. (2012). Plasma multianalyte profiling in mild cognitive impairment and Alzheimer Disease. Neurology, 79(9), 897-905. https://doi.org/10.1212/WNL.0b013e318266fa70

[35] Huang, C. W., Wang, S. J., Wu, S. J., Yang, C. C., Huang, M. W., Lin, C. H., \& Cheng, I. H. (2013). Potential blood biomarker for disease severity in the taiwanese population with Alzheimer's disease. American Journal of Alzheimer's Disease and Other Dementias, 28(1),75-83. https://doi.org/10.1177/1533317512467674

[36] Jongbloed, W., Van Dijk, K. D., Mulder, S. D., Van De Berg, W. D. J., Blankenstein, M. A., Van Der Flier, W., \& Veerhuis, R. (2015). Clusterin Levels in Plasma Predict Cognitive Decline and Progression to Alzheimer's Disease. Journal of Alzheimer's Disease, 46(4), 1103-1110. https://doi.org/10.3233/JAD-150036

[37] Kamer, A. R., Craig, R. G., Pirraglia, E., Dasanayake, A. P., Norman, R. G., Boylan, R. J., ... de Leon, M. J. (2009). TNF- $\alpha$ and antibodies to periodontal bacteria discriminate between Alzheimer's disease patients and normal subjects. Journal of Neuroimmunology, 216(1-2),92-97. https://doi.org/10.1016/j.jneuroim.2009.08.013

[38] Kiddle, S. J., Steves, C. J., Mehta, M., Simmons, A., Xu, X., Newhouse, S., .. Dobson, R. J. B. (2015). Plasma protein biomarkers of Alzheimer's disease endophenotypes in asymptomatic older 
twins: early cognitive decline and regional brain volumes. Translational Psychiatry, 5(6), 2-7. https://doi.org/10.1038/tp.2015.78

[39] Kim, S. M., Song, J., Kim, S., Han, C., Park, M. H., Koh, Y., ... Kim, Y. Y. (2011). Identification of peripheral inflammatory markers between normal control and Alzheimer's disease. BMC Neurology, 11, 2-7. https://doi.org/10.1186/1471-2377-11-51

[40] Kitamura, Y., Usami, R., Ichihara, S., Kida, H., Satoh, M., Tomimoto, H., ... Oikawa, S. (2017). Plasma protein profiling for potential biomarkers in the early diagnosis of Alzheimer's disease. Neurological Research, 39(3), 231-238. https://doi.org/10.1080/01616412.2017.1281195

[41] Lawrence, E., Vegvari, C., Ower, A., Hadjichrysanthou, C., De Wolf, F., \& Anderson, R. M. (2017). A Systematic Review of Longitudinal Studies Which Measure Alzheimer's Disease Biomarkers. Journal of Alzheimer's Disease, 59(4), 1359-1379. https://doi.org/10.3233/JAD170261

[42] Lemańska-Perek, A., Leszek, J., Krzyanowska-Golạb, D., Radzik, J., \& Kạtnik-Prastowska, M. I. (2009). Molecular status of plasma fibronectin as an additional biomarker for assessment of alzheimer's dementia risk. Dementia and Geriatric Cognitive Disorders, 28(4), 338-342. https://doi.org/10.1159/000252764

[43] Leroi, I., Voulgari, A., Breitner, J. C. S., \& Lyketsos, C. G. The epidemiology of psychosis in dementia. The American Journal of Geriatric Psychiatry: Official Journal of the American Association for Geriatric Psychiatry, 11(1), 83-91. Retrieved from http://www.ncbi.nlm.nih.gov/pubmed/12527543

[44] Liang, F., Jia, J., Wang, S., Qin, W., \& Liu, G. (2013). Decreased plasma levels of soluble low density lipoprotein receptor-related protein-1 (sLRP) and the soluble form of the receptor for advanced glycation end products (sRAGE) in the clinical diagnosis of Alzheimer's disease. Journal of Clinical Neuroscience, 20(3), 357-361. https://doi.org/10.1016/j.jocn.2012.06.005

[45] Lim, N. K. H., Villemagne, V. L., Soon, C. P. W., Laughton, K. M., Rowe, C. C., McLean, C. A., ... Li, Q. X. (2011). Investigation of matrix metalloproteinases, MMP-2 and MMP-9, in plasma reveals a decrease of MMP-2 in Alzheimer's disease. Journal of Alzheimer's Disease, 26(4), 779786. https://doi.org/10.3233/JAD-2011-101974

[46] Llano, D. A., Devanarayan, V., \& Simon, A. J. (2013). Evaluation of Plasma Proteomic Data for Alzheimer Disease State Classification and for the Prediction of Progression From Mild Cognitive Impairment to Alzheimer Disease. Alzheimer Disease \& Associated Disorders, 27(3), 233-243. https://doi.org/10.1097/WAD.0b013e31826d597a

[47] Marcello, A., Wirths, O., Schneider-Axmann, T., Degerman-Gunnarsson, M., Lannfelt, L., \& Bayer, T. A. (2011). Reduced levels of IgM autoantibodies against N-truncated pyroglutamate A $\beta$ in plasma of patients with Alzheimer's disease. Neurobiology of Aging, 32(8), 1379-1387. https://doi.org/10.1016/j.neurobiolaging.2009.08.011

[48] Marksteiner, J., Imarhiagbe, D., Defrancesco, M., Deisenhammer, E. A., Kemmler, G., \& Humpel, C. (2013). Analysis of 27 vascular-related proteins reveals that NT-proBNP is a potential biomarker for Alzheimer's disease and mild cognitive impairment: A pilot-study. Experimental Gerontology, 50(1), 114-121. https://doi.org/10.1016/j.exger.2013.12.001

[49] Mathuranath, P. S., George, A., Ranjith, N., Justus, S., Kumar, M. S., Menon, R., ... Verghese, J. (2012). Incidence of Alzheimer's disease in India: a 10 years follow-up study. Neurology India, 60(6), 625-630. https://doi.org/10.4103/0028-3886.105198

[50] Mielke, M. M., Haughey, N. J., Bandaru, V. V. R., Weinberg, D. D., Darby, E., Zaidi, N., ... Lyketsos, C. G. (2011). Plasma sphingomyelins are associated with cognitive progression in alzheimer's disease. Journal of Alzheimer's Disease, 27(2), 259-269. https://doi.org/10.3233/JAD2011-110405

[51] O’Bryant, S. E., Johnson, L., Edwards, M., Soares, H., Devous, M. D., Ross, S., ... Texas Alzheimer's Research \& Care Consortium, J. (2013). The link between C-reactive protein and Alzheimer's disease among Mexican Americans. Journal of Alzheimer's Disease : JAD, 34(3), 701-706. https://doi.org/10.3233/JAD-122071

[52] O’Bryant, S. E., Mielke, M. M., Rissman, R. A., Lista, S., Vanderstichele, H., Zetterberg, H., ... Biofluid Based Biomarker Professional Interest Area, the B. B. B. P. I. (2017). Blood-based 
biomarkers in Alzheimer disease: Current state of the science and a novel collaborative paradigm for advancing from discovery to clinic. Alzheimer's \& Dementia: The Journal of the Alzheimer's Association, 13(1), 45-58. https://doi.org/10.1016/j.jalz.2016.09.014

[53] Oh, J., Lee, H. J., Song, J. H., Park, S. I., \& Kim, H. (2014). Plasminogen activator inhibitor-1 as an early potential diagnostic marker for Alzheimer's disease. Experimental Gerontology, 60, 8791. https://doi.org/10.1016/j.exger.2014.10.004

[54] Park, J., Park, J., Lee, J., \& Choi, C. (2014). Evaluation and Identification of Protein Blood Biomarkers for Alzheimer's Disease: A Systematic Review and Integrative Analysis. Journal of Molecular Biomarkers \& Diagnosis, 5(5).https://doi.org/10.4172/2155-9929.1000190

[55] Parker, D. C., Mielke, M. M., Yu, Q., Rosenberg, P. B., Jain, A., Lyketsos, C. G., ... Oh, E. S. (2013). Plasma neopterin level as a marker of peripheral immune activation in amnestic mild cognitive impairment and Alzheimer's disease. International Journal of Geriatric Psychiatry, 28(2), 149-154. https://doi.org/10.1002/gps.3802

[56] Peng, M., Jia, J., \& Qin, W. (2015). Plasma gelsolin and matrix metalloproteinase 3 as potential biomarkers for Alzheimer disease. Neuroscience Letters, 595, 116-121. https://doi.org/10.1016/j.neulet.2015.04.014

[57] Piscopo, P., Rivabene, R., Galimberti, D., Crestini, A., Talarico, G., Vanacore, N., ... Confaloni, A. (2013). Gender effects on plasma PGRN levels in patients with Alzheimer's disease: A preliminary study. Journal of Alzheimer's Disease, 35(2), 313-318. https://doi.org/10.3233/JAD-121606

[58] Querfurth, H. W., \& LaFerla, F. M. (2010). Alzheimer's Disease. New England Journal of Medicine, 362(4), 329-344. https://doi.org/10.1056/NEJMra0909142

[59] Rani, P., Krishnan, S., \& Rani Cathrine, C. (2017). Study on Analysis of Peripheral Biomarkers for $\begin{array}{llllll}\text { Alzheimer's Disease Diagnosis. Frontiers in Neurology, } 8, & 328 .\end{array}$ https://doi.org/10.3389/fneur.2017.00328

[60] Richens, J. L., Spencer, H. L., Butler, M., Cantlay, F., Vere, K. A., Bajaj, N., ... O’Shea, P. (2016). Rationalising the role of Keratin 9 as a biomarker for Alzheimer's disease. Scientific Reports, 6(March), 1-12. https://doi.org/10.1038/srep22962

[61] Schmidt, R., Schmidt, H., Curb, J. D., Masaki, K., White, L. R., \& Launer, L. J. (2002) Early inflammation and dementia: A 25- year follow-up of the Honolulu-Asia Aging Study. Annals of Neurology 52, 168-174. https://doi.org/10.1002/ana.10265

[62] Schneider, P., Hampel, H., \& Buerger, K. (2009). Biological Marker Candidates of Alzheimer's Disease in Blood, Plasma, and Serum. CNS Neuroscience \& Therapeutics, 15(4), 358-374. https://doi.org/10.1111/j.1755-5949.2009.00104.x

[63] Schrijvers, E. M. C., Koudstaal, P. J., Hofman, A., \& Breteler, M. M. B. (2011). Plasma clusterin and the risk of Alzheimer disease. JAMA - Journal of the American Medical Association, 305(13), 1322-1326. https://doi.org/10.1001/jama.2011.381

[64] Shih, Y. H., Tsai, K. J., Lee, C. W., Shiesh, S. C., Chen, W. T., Pai, M. C., \& Kuo, Y. M. (2014). Apolipoprotein C-III is an amyloid- $\beta$-binding protein and an early marker for Alzheimer's disease. Journal of Alzheimer's Disease : JAD, 41(3), 855-865. https://doi.org/10.3233/JAD-140111

[65] Soares, H. D., Potter, W. Z., Pickering, E., Kuhn, M., Immermann, F. W., Shera, D. M., ... Shaw, L. M. (2012). Plasma biomarkers associated with the apolipoprotein E genotype and alzheimer disease. Archives of Neurology, 69(10), 1310-1317. https://doi.org/10.1001/archneurol.2012.1070

[66] Stages of Alzheimer's \&amp; Symptoms I Alzheimer's Association. Retrieved April 22, 2018, from https://www.alz.org/alzheimers_disease_stages_of_alzheimers.asp

[67] Sun, L., Tan, M. S., Hu, N., Yu, J. T., \& Tan, L. (2013). Exploring the value of plasma BIN1 as a potential biomarker for alzheimer's disease. J Alzheimers Dis, 37(2), 291-295. https://doi.org/10.3233/JAD-130392

[68] Terry, R. D. (2006). Alzheimer's Disease and the Aging Brain. Journal of Geriatric Psychiatry and Neurology, 19(3), 125-128. https://doi.org/10.1177/0891988706291079

[69] Une, K., Takei, Y. A., Tomita, N., Asamura, T., Ohrui, T., Furukawa, K., \& Arai, H. (2011). Adiponectin in plasma and cerebrospinal fluid in MCI and Alzheimer's disease. European Journal of Neurology, 18(7), 1006-1009. https://doi.org/10.1111/j.1468-1331.2010.03194.x 
[70] Velayudhan, L., Killick, R., Hye, A., Kinsey, A., Güntert, A., Lynham, S., ... Lovestone, S. (2012). Plasma transthyretin as a candidate marker for Alzheimer's disease. Journal of Alzheimer's Disease, 28(2), 369-375. https://doi.org/10.3233/JAD-2011-110611

[71] Waragai, M., Yoshida, M., Mizoi, M., Saiki, R., Kashiwagi, K., Takagi, K., ... Igarashi, K. (2012). Increased protein-conjugated acrolein and amyloid- $\beta 40 / 42$ ratio in plasma of patients with mild cognitive impairment and Alzheimer's disease. Journal of Alzheimer's Disease, 32(1), 33-41. https://doi.org/10.3233/JAD-2012-120253

[72] What Causes Alzheimer's? I Capo Therapeutics, Inc. Retrieved April 22, 2018, from http://capotherapeutics.com/what-causes-alzheimers/

[73] What Causes Alzheimer's Disease? Retrieved April 22, 2018, from https://www.nia.nih.gov/health/what-causes-alzheimers-disease

[74] Wu, G., Sankaranarayanan, S., Wong, J., Tugusheva, K., Michener, M. S., Shi, X., ... Savage, M. J. (2012). Characterization of plasma ??-secretase (BACE1) activity and soluble amyloid precursor proteins as potential biomarkers for Alzheimer's disease. Journal of Neuroscience Research, 90(12), 2247-2258. https://doi.org/10.1002/jnr.23122

[75] Yarchoan, M., Louneva, N., Xie, S. X., Swenson, F. J., Hu, W., Soares, H., ... Arnold, S. E. (2013). Association of plasma C-reactive protein levels with the diagnosis of Alzheimer's disease. Journal of the Neurological Sciences, 333(1-2), 9-12. https://doi.org/10.1016/j.jns.2013.05.028

[76] Yoshida, Y., Yoshikawa, A., Kinumi, T., Ogawa, Y., Saito, Y., Ohara, K., ... Niki, E. (2009). Hydroxyoctadecadienoic acid and oxidatively modified peroxiredoxins in the blood of Alzheimer's disease patients and their potential as biomarkers. Neurobiology of Aging, 30(2), 174-185. https://doi.org/10.1016/j.neurobiolaging.2007.06.012

[77] Zengi, O., Karakas, A., Ergun, U., Senes, M., Inan, L., \& Yucel, D. (2012). Urinary 8-hydroxy-2'deoxyguanosine level and plasma paraoxonase 1 activity with Alzheimer's disease. Clinical Chemistry and Laboratory Medicine, 50(3), 529-534. https://doi.org/10.1515/cclm.2011.792

[78] Zhang, J., Jia, J., Qin, W., \& Wang, S. (2013). Combination of plasma tumor necrosis factor receptors signaling proteins, beta-amyloid and apolipoprotein $\mathrm{E}$ for the detection of Alzheimer's disease. Neuroscience Letters, 541, 99-104. https://doi.org/10.1016/j.neulet.2013.03.007

[79] Zheng, L., Kong, X., Cui, Y., Wei, Y., Zhang, J., \& Wei, W. (2016). Conversion from MCI to AD in patients with the APOE $\varepsilon 4$ genotype: Prediction by plasma HCY and serum BDNF. Neuroscience Letters, 626, 19-24. https://doi.org/10.1016/j.neulet.2016.05.018

[80] Zuliani, G., Donnorso, M. P., Bosi, C., Passaro, A., Dalla Nora, E., Zurlo, A.,Cortese, C. (2011). Plasma 24S-hydroxycholesterol levels in elderly subjects with late onset Alzheimer's disease or vascular dementia: a case-control study. BMC Neurology, 11(1), 121. https://doi.org/10.1186/14712377-11-121 